\title{
Biosynthesis of vitamin $B_{12}$ : the preparative multi-enzyme synthesis of precorrin-3A and 20-methylsirohydrochlorin (a 2,7,20-trimethylisobacteriochlorin)
}

\author{
N. Patrick J. STAMFORD, ${ }^{\star}$ Joël CROUZET, $\uparrow$ Béatrice CAMERON, $\dagger$ Alex I. D. ALANINE, ${ }^{\star}$ Andrew R. PITT, Alexei A. YELISEEV* \\ and Alan R. BATTERSBY*+ \\ *University Chemical Laboratory, University of Cambridge, Lensfield Road, Cambridge CB2 1EW, U.K., and †Department Analyse, Centre de Recherché de Alfortville, \\ Rhône-Poulenc Rorer, BP14, F-94403, Vitry-sur-Seine Cedex, France
}

The Bacillus subtilis genes hemB, hem $C$ and hemD, encoding respectively the enzymes porphobilinogen synthase, hydroxymethylbilane synthase and uroporphyrinogen III synthase, have been expressed in Escherichia coli using a single plasmid construct. An enzyme preparation from this source converts 5aminolaevulinic acid (ALA) preparatively and in high yield into uroporphyrinogen III. The Pseudomonas denitrificans genes cobA and cobI, encoding respectively the enzymes $S$-adenosyl-L-methionine:uroporphyrinogen III methyltransferase (SUMT) and $S$ adenosyl-L-methionine:precorrin-2 methyltransferase $\left(\mathrm{SP}_{2} \mathrm{MT}\right)$, were also expressed in E. coli. When SUMT was combined with the coupled-enzyme system that produces uroporphyrinogen III, precorrin-2 was synthesized from ALA, and when $\mathrm{SP}_{2} \mathrm{MT}$ was also added the product from the coupling of five enzymes was precorrin-3A. Both of these products are precursors of vitamin $\mathrm{B}_{12}$, and they can be used directly for biosynthetic experiments or isolated as their didehydro octamethyl esters in $>40 \%$ overall yield. The enzyme system which produces precorrin-3A is sufficiently stable to allow long incubations on a large scale, affording substantial quantities $(15-20 \mathrm{mg})$ of product.

\section{INTRODUCTION}

A scientist confronted with the structure of vitamin $\mathrm{B}_{12}$ (7) see Scheme 1) is bound to wonder how such a molecular assembly is built in the living system. Prior to the late 1960s, most studies of such biosynthetic problems were carried out using ${ }^{14} \mathrm{C}$ or ${ }^{3} \mathrm{H}$ as radioactive tracers. Because of the sensitivity of detection of radioactivity, these experiments could be successful even with minute conversions (1-5 $\mu \mathrm{g}$ or less) of labelled precursor into labelled product. Though ${ }^{14} \mathrm{C}$ and ${ }^{3} \mathrm{H}$ have continued to be used for some specific studies on vitamin $\mathrm{B}_{12}$, the dramatic advances during the past 6 years or so could not have been achieved in that way. These advances have recently culminated in the definition of the entire sequence of intermediates on the pathway to vitamin $\mathrm{B}_{12}[1,2]$. Two developments contributed decisively to this success.

The first was the use of ${ }^{13} \mathrm{C}$-labelling in combination with NMR spectroscopy to follow biosynthetic conversions, since this allows biochemical changes to be studied simultaneously at many ${ }^{13} \mathrm{C}$-labelled sites in the same complex molecule. It was this approach that contributed strongly to making the breakthrough in the $\mathrm{B}_{12}$ biosynthetic problem in $1990[3,4]$ and which set in motion the rapid advance to the final solution. The power of ${ }^{13} \mathrm{C}$ labelling had been demonstrated before that event by many studies in the $\mathrm{B}_{12}$ field $[5,6]$ and others.

The second development was the addition of molecular genetics and enzymology to the armoury used to attack the $\mathrm{B}_{12}$ biosynthetic problem; the way this can be done is reviewed in [1,7]. These methods allowed each enzyme carrying out a specific biosynthetic transformation on the pathway to vitamin $\mathrm{B}_{12}$ to be pinpointed, and provided enzymes in substantial amounts. This was of critical importance because, in contrast to the situation when radioactive isotopes were used, ${ }^{13} \mathrm{C}$-labelling demands greater quantities of material and hence more enzyme. Indeed, several of our key experiments [1] involved transformation of the ${ }^{13} \mathrm{C}$-labelled substrate through five to seven enzymic steps to give products from which pure isomers had to be isolated in a stable form. Substantial amounts (10-20 mg) of ${ }^{13} \mathrm{C}$-labelled precursor were required for such work. It was clear from around 1990 when the breakthrough on $\mathrm{B}_{12}$ was made [3,4], and from experience of the non-enzymic synthesis of $\mathrm{B}_{12}$ intermediates [8-10], that relatively large-scale enzymic syntheses of some of the early precursors of vitamin $\mathrm{B}_{12}$ had to be developed for the ${ }^{13} \mathrm{C}$ labelling studies; this work is described in the present paper. Valuable work on similar enzymic syntheses of these intermediates was carried out at about the same time elsewhere $[3,11,12]$. It appears that the enzymic system used here has the advantage of being more stable, thus allowing long incubation times on a large scale, and so is valuable for the preparation of substantial quantities of material.

Scheme 1 shows the early part of the biosynthetic pathway to vitamin $\mathrm{B}_{12}$ (7) as far as the trimethylated intermediate, precorrin$3 \mathrm{~A}(6)$. This is committed irreversibly to the $\mathrm{B}_{12}$ pathway and is efficiently carried forward by cell-free enzyme systems from $\mathrm{B}_{12}{ }^{-}$ producing organisms. Accordingly, precorrin-3A was our main target, and its enzymic synthesis in 10-20 mg amounts required the preparation of large quantities of each of the five enzymes involved in its biosynthesis (see Scheme 1). These are porphobilinogen (PBG) synthase (EC 4.2.1.24), hydroxymethylbilane

Abbreviations used: ALA, 5-aminolaevulinic acid; HMB, hydroxymethylbilane; PBG, porphobilinogen; AdoHcy, S-adenosylhomocysteine; AdoMet, S-adenosyl-L-methionine; $\mathrm{SP}_{2} \mathrm{MT}$, S-adenosyl-L-methionine:precorrin-2 methyltransferase; SUMT, S-adenosyl-L-methionine:uroporphyrinogen III methyltransferase; THF, tetrahydrofuran; TMIBC, trimethylisobacteriochlorin.

* To whom correspondence should be addressed. 


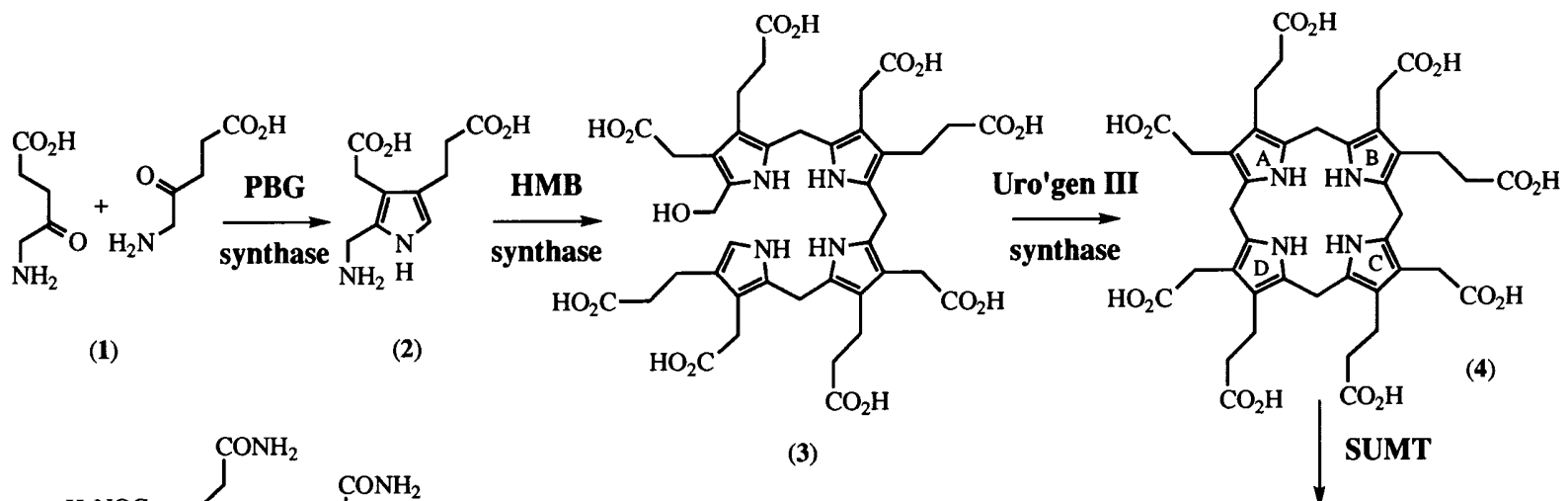

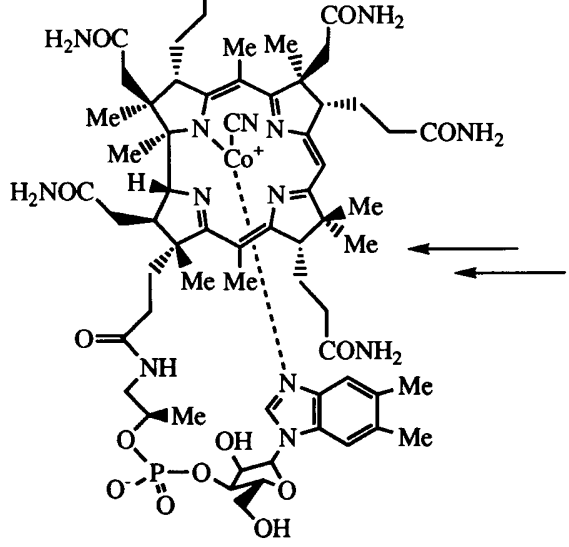

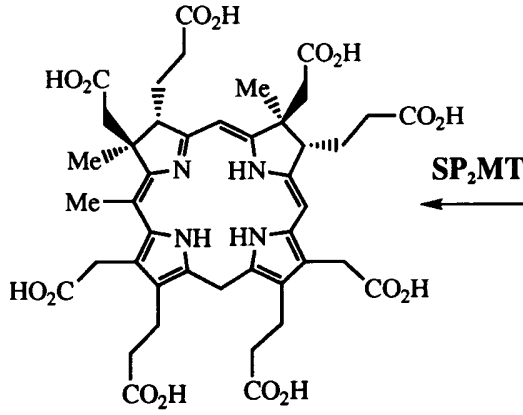

(6)

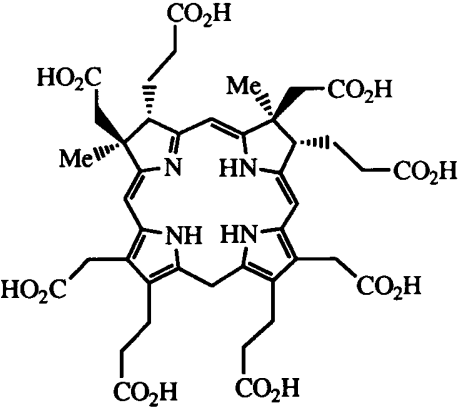

(5)

(7)<smiles></smiles>

(8)

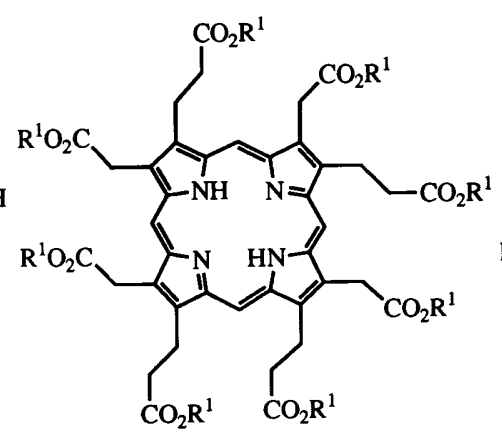

(9a) $\mathrm{R}^{1}=\mathrm{H}$

(9b) $\mathrm{R}^{1}=\mathrm{Me}$

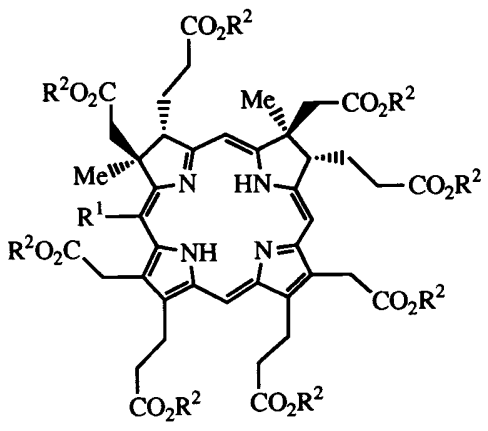

(10a) $\mathrm{R}^{1}=\mathrm{H}, \mathrm{R}^{2}=\mathrm{H}$

(10b) $\mathrm{R}^{1}=\mathrm{H}, \mathrm{R}^{2}=\mathrm{Me}$

(11a) $\mathrm{R}^{1}=\mathrm{Me}, \mathrm{R}^{2}=\mathrm{H}$

(11b) $\mathrm{R}^{1}=\mathrm{Me}, \mathrm{R}^{2}=\mathrm{Me}$

\section{Scheme 1 Biosynthesis of precorrin-2 (5) and precorrin-3A (6) on the pathway to vitamin $B_{12}$}

$\mathbf{1}, \mathrm{ALA} ; \mathbf{2}, \mathrm{PBG} ; \mathbf{3}, \mathrm{HMB} ; \mathbf{4}$, uroporphyrinogen III; $\mathbf{5}$, precorrin-2; $\mathbf{6}$, precorrin-3A; $\mathbf{7}$, vitamin $\mathrm{B}_{12} ; \mathbf{8}$, uroporphyrinogen I; $\mathbf{9 a}$, uroporphyrin III and its methyl ester $\mathbf{9 b} ; \mathbf{1 0 a}$, sirohydrochlorin and its methyl ester 10b; 11a, trimethylisobacteriochlorin and its methyl ester 11b. Enzymes: PBG synthase ( $\equiv$ ALA dehydratase); HMB synthase ( $\equiv$ PBG deaminase); uroporphyrinogen (uro'gen) III synthase (三 cosynthetase); SUMT; $\mathrm{SP}_{2} \mathrm{MT}$.

(HMB) synthase (EC 4.3.1.8) and uroporphyrinogen III synthase (EC 4.2.1.75), together with the first and second methyltransferases of the $\mathrm{B}_{12}$ pathway, which are $S$-adenosyl-L-methionine (AdoMet)-dependent. For reasons which will become clear later, we wished to complete the syntheses from both the simple 5-carbon building block 5-aminolaevulinic acid (ALA) (1) and from the tetrapyrrolic macrocycle uroporphyrinogen III (4). The product was isolated as the octamethyl ester (11b) of its aromatized form, the trimethylisobacteriochlorin (TMIBC) (11a).

\section{EXPERIMENTAL}

\section{General experimental}

Electronic spectra were recorded on a Cecil CE 5501 UV spectrophotometer. Electrospray mass spectrometry was per- 
Table 1 Bacterial strains and plasmid DNAs

\begin{tabular}{|c|c|c|c|}
\hline Bacterial strain or plasmid & Marker and replicon & Relevant properties & Reference or source \\
\hline \multicolumn{4}{|l|}{ E. coli } \\
\hline AN1459 & & ilv thr supE recA srl:: $\operatorname{Tn} 10$ & {$[13]$} \\
\hline MC1060 & & $\Delta($ laclPOZYA $X 74$ galU galK strA2 hsdR & {$[14]$} \\
\hline BL21(DE3) & & hsdS gal( $\lambda$ clts857 Sam7 nin5 ind1 lacUV5-T7 gene 1) & {$[15]$} \\
\hline TG1 & & $\Delta$ (lac-pro) thi supE hsdD5/F' proAB lac/ ${ }^{\natural} Z \Delta M 15$ & {$[15 a]$} \\
\hline \multicolumn{4}{|l|}{ Plasmids } \\
\hline pXL694 & Amp ${ }^{r}$ ColE1 & Carries $E$. coli trp operon and ribosome-binding site of the $\lambda c \|$ gene & {$[16]$} \\
\hline pLysS & $\mathrm{Cm}^{r}$ pACYC184 & Carries T7 lysozyme gene & {$[17]$} \\
\hline pET-3a & Amp $^{r}$ ColE1 & Carries $T 7 \phi 10$ promoter & {$[18]$} \\
\hline pPS436 & Amp ColE1 & Carries bacteriophage $\lambda$ promoters and $c \mid 857$ allele & {$[15 b]$} \\
\hline pXL151 & $\mathrm{Km}^{\mathrm{r}} \mathrm{RSF} 1010$ & Contains $P$. denitrificans cobFGHIJKLM gene cluster & [19] \\
\hline pXL157 & $\mathrm{Km}^{r} \mathrm{RSF} 1010$ & Contains $P$. denitrificans cobO gene and $\operatorname{cobEABCD}$ gene cluster & {$[19]$} \\
\hline pLUX3201 & Ampr ColE1 & Contains $B$. subtilis hemAXCDBL gene cluster & [20] \\
\hline M13mp11 & f1 & M13 bacteriophage derivative & [21] \\
\hline M13tg131 & $f 1$ & M13 bacteriophage derivative & [22] \\
\hline pPS16 & Amp $p^{r}$ ColE1 & 4.6 kb pLUX3201 Bg/II/Smal (hemXCDB) fragment cloned into pPS436 & This study \\
\hline pXL1253 & $f 1$ & $2.4 \mathrm{~kb}$ pXL1235 Clal/EcoRV (CobA) fragment cloned into Sall/Smal sites of M13mp11 & This study \\
\hline pXL1262 & f1 & Site-directed mutant derivative of pXL1235 with an Ndel site insertion & This study \\
\hline pXL1283 & Amp $p^{r}$ ColE1 & $1.3 \mathrm{~kb}$ pXL1262 Ndel/Sstl (cobA) fragment cloned into pXL694 & This study \\
\hline pXL1110 & f1 & $1.5 \mathrm{~kb}$ pXL151 BamHI/Sstl-Sstl (cob/) fragment cloned into M13tg131 & This study \\
\hline pXL1306 & $f 1$ & Site-directed mutant derivative of pXL1110 with an Ndel site insertion & This study \\
\hline pXL1455 & Ampr ColE1 & 0.9 kb pXL1306 Ndel/Sstl-Sstl (cob/) fragment cloned into pXL694 & This study \\
\hline pXL1492 & Ampr ColE1 & $0.9 \mathrm{~kb}$ pXL1455 Ndel/BamHI (cob/) fragment cloned into pET-3a & This study \\
\hline
\end{tabular}

formed on a VG quadrupole mass spectrometer using VG Lab Base software (VG Analytical). NMR spectra were recorded on a Bruker WH-400 instrument operating at $400 \mathrm{MHz}$ for ${ }^{1} \mathrm{H}-$ spectra and $100.6 \mathrm{MHz}$ for ${ }^{13} \mathrm{C}$-spectra, and the solvent signal was used as internal reference. HPLC purifications were carried out using a Waters 600E multisolvent delivery system, and pigments were detected by a Cecil CE 272 UV spectrophotometer equipped with a Venture RE 511.20 recorder. The reverse-phase column was a Hichrom S 5 ODS $1(4.6 \mathrm{~mm} \times 250 \mathrm{~mm})$ and, before injection, samples were filtered through Acrodisc 3 (0.45 mm; Gelman Sciences). Sep-Pak C-18 cartridges were from Waters. Preparative TLC was performed on plates coated to $1 \mathrm{~mm}$ with Kieselgel H60 (Merck). Radiochemical analyses were carried out on a United Technologies Packard 2000 CA Tricarb liquid scintillation analyser. Centrifugations were performed on a Europa $24 \mathrm{M}$ centrifuge, and large-scale fermentations were performed in a Microferm fermentor (New Brunswick Scientific) with constant stirring (200 rev./min) and an air flow $\left(41 \mathrm{~min}^{-1}\right)$ using a Radiometer type TTT2 auto-titrator for $\mathrm{pH}$ control. All solvents were dried prior to use and water used throughout was distilled and further purified with a MilliQ system (Millipore). Solvents were evaporated on a Büchi Rotavapor at reduced pressure.

\section{Bacterial strains and DNA}

Bacterial strains and plasmid DNAs are listed in Table 1. Escherichia coli AN1459 (ilv thr supE recA srl::Tn10) [13], MC1060 [ $\triangle($ lacIPOZYA)X74 galU galK strA2 hsdR) [14] and BL21(DE3) [ $h s d S$ gal( $\lambda c$ Its857 Sam7 nin5 ind1 lacUV5-T7 gene 1)] [15] were used as hosts for all plasmids. E. coli TG1 [ $\Delta$ (lac-

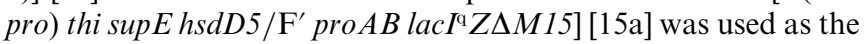
recipient host for all M13 derivatives. Bacteria were grown at $37^{\circ} \mathrm{C}$ in LB broth or plates. For E. coli strain AN1459, cultures were grown at $30{ }^{\circ} \mathrm{C}$ and media were supplemented with thymine $\left(25 \mu \mathrm{g} \cdot \mathrm{ml}^{-1}\right)$. Antibiotic supplements where used were ampicillin $\left(50 \mu \mathrm{g} \cdot \mathrm{ml}^{-1}\right)$ and chloramphenicol $\left(20 \mu \mathrm{g} \cdot \mathrm{ml}^{-1}\right)$. Plasmids pPS436 (kindly provided by Dr. N. E. Dixon, Australian
National University, Canberra, ACT, Australia) [15b], pXL694 [16], pLysS [17], pET-3a [18], pXL151 [19], pXL157 [19] and pLUX3201 (kindly provided by Dr. L. Hederstedt, University of Lund, Lund, Sweden) [20] and bacteriophage M13mp11 [21] and M13tg131 [22] were as described. Oligonucleotides were synthesized on an Applied Biosystems oligonucleotide synthesizer and oligonucleotide-directed mutagenesis was performed using the system of Amersham. All other procedures used for DNA manipulations were essentially as described [23].

\section{Reagents, chromatographic resins and enzymes}

Enzymes used for DNA manipulations were obtained from Stratagene, Pharmacia or Boehringer-Mannheim and were used in buffers recommended by the suppliers. Reagents and buffer components, lysozyme, antibiotics and AdoMet were from Sigma. Radioactive [methyl $\left.-{ }^{14} \mathrm{C}\right]$ AdoMet $\left(53 \mu \mathrm{Ci} \cdot \mu \mathrm{mol}^{-1}\right)$ was from Amersham, DEAE-cellulose from Whatman and culture media from Difco. HMB synthase from E. coli was purified [24] and the substrates ALA [25] and PBG [26] were synthesized essentially as described.

\section{Plasmid constructions}

\section{Construction of pPS16}

The Bacillus subtilis hemB, hem $C$ and hemD genes were expressed in $E$. coli following the cloning of a $B$. subtilis chromosomal fragment downstream of the bacteriophage $\lambda P_{\mathrm{R}}$ promoter in the pCE30 [27]-derived vector pPS436. Plasmid pPS16 (8.3 kb) was constructed by ligation of the $4.6 \mathrm{~kb} B g / \mathrm{II} / S m a \mathrm{I}$ fragment containing the $B$. subtilis hem $X C D B$ gene cluster from pLUX3201 [20] into the BglII and SmaI sites of pPS436.

\section{Construction of pXL1283}

The Pseudomonas denitrificans cobA gene was expressed in E. coli following the insertion of the $\operatorname{cob} A$ gene downstream of the $\operatorname{trp}$ 
promoter in the pBR322-derived expression vector pXL694. Initially a $2.4 \mathrm{~kb} C l a \mathrm{I} / E c o \mathrm{RV}$ fragment carrying the $P s$. denitrificans $\operatorname{cobA}$ gene from pXL157 [19] was ligated into the SalI and SmaI sites of M13mp11 to give pXL1235. Oligonucleotide site-directed mutagenesis [28] was then performed using oligonucleotide 364 (5'-GGTCGTCGATCATATGTGCTGTCCCACC-3') to construct an NdeI restriction site (underlined) over the translation initiation signal (ATG) of the $\operatorname{cob} A$ gene. A $1.3 \mathrm{~kb}$ $N d e I / S s t$ I fragment from this new construct (pXL1262) containing the $\operatorname{cob} A$ gene was then cloned into the NdeI and SstI sites of pXL694 to give the $4.5 \mathrm{~kb}$ cobA expression vector pXL1283.

\section{Construction of pXL1492}

The Ps. denitrificans cobI gene was expressed in E. coli following the insertion of the cobI gene downstream of the $\Phi 10 \mathrm{~T} 7$ promoter in the expression vector pET-3a. Initially a $1.5 \mathrm{~kb}$ Bam HI/SstI-Sst I fragment containing the Ps. denitrificans cobI gene from pXL151 [19] was ligated into the BamHI and SstI sites of M13tg131 giving pXL1110 (8.7 kb). Oligonucleotide sitedirected mutagenesis [28] was then performed using oligonucleotide 457 (5'-CGCCGACGCCGCTCATATGCCCGGCCTCGCGAGC-3') to construct an NdeI restriction site (underlined) over the translation initiation signal (ATG) of the cobI

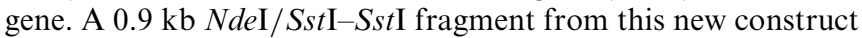
(pXL1306; $8.7 \mathrm{~kb}$ ) containing the $\operatorname{cobI}$ gene was then cloned into the NdeI and SstI sites of pXL694 to give pXL1455 $(4.1 \mathrm{~kb})$. Finally, the $0.9 \mathrm{~kb} \mathrm{NdeI/BamHI} c o b I$ containing fragment of pXL1455 was cloned into the NdeI and BamHI sites of pET-3a to give the cobI expression vector pXL1492 (5.4 kb).

\section{Enzyme assays}

PBG synthase and HMB synthase activities were determined essentially as described $[29,30]$ using ALA and PBG respectively as substrates for the reactions. Uroporphyrinogen III synthase activity was determined using a coupled assay in which the enzyme HMB synthase is used to generate the substrate HMB [31]. In each case 1 unit of enzyme activity is the amount of enzyme required to form $1 \mu \mathrm{mol}$ of product per $\mathrm{h}$.

\section{Protein chemistry}

Lysis of cells

Chilled cell cultures were harvested $(12000 \mathrm{~g}, 15 \mathrm{~min})$, resuspended to a density where $D_{595} \sim 200$ in $100 \mathrm{mM}$ Tris $/ \mathrm{HCl}$ (pH 7.6)/10\% (w/v) sucrose, poured into liquid $\mathrm{N}_{2}$ and stored at $-70{ }^{\circ} \mathrm{C}$. Cells were thawed and diluted to $D_{595} \sim 50$ in the final composition of lysis buffer [100 mM Tris/ $\mathrm{HCl}(\mathrm{pH} 7.6), 10 \%$ (w/v) sucrose, $100 \mathrm{mM} \mathrm{NaCl}, 4 \mathrm{mM}$ dithiothreitol, $10 \mathrm{mM}$ spermidine $/ \mathrm{HCl}, \quad 0.1 \%$ (v/v) Triton X-100]. Lysozyme $\left(0.2 \mathrm{mg} \cdot \mathrm{ml}^{-1}\right)$ was added and the mixture was stirred for $1 \mathrm{~h}$ at $0{ }^{\circ} \mathrm{C}$. Cell-free extracts were then prepared by centrifugation $(40000 \mathrm{~g}, 30 \mathrm{~min})$. All procedures during the partial purification of proteins were carried out at $0-5{ }^{\circ} \mathrm{C}$.

\section{Extraction of PBG synthase, HMB synthase and uroporphyrinogen III synthase}

E. coli AN1459/pPS16 was grown at $30^{\circ} \mathrm{C}$ in LB broth (12 1) supplemented with ampicillin $\left(50 \mu \mathrm{g} \cdot \mathrm{ml}^{-1}\right)$ and thymine $\left(25 \mu \mathrm{g} \cdot \mathrm{ml}^{-1}\right)$ to $D_{595}=0.65$. After a rapid temperature shift to $42{ }^{\circ} \mathrm{C}$, growth was continued at $42{ }^{\circ} \mathrm{C}$ for $4 \mathrm{~h}$. The culture was chilled and cells were harvested and lysed as already described.
To the cell-free extract obtained after centrifugation was added solid ammonium sulphate $\left(0.6 \mathrm{~g} \cdot \mathrm{ml}^{-1}\right)$. After being stirred for $1 \mathrm{~h}$, the suspension was centrifuged $(40000 \mathrm{~g}, 45 \mathrm{~min})$ and the pellet obtained could be resuspended for use in enzymic incubations or was frozen in liquid $\mathrm{N}_{2}$ and stored at $-70^{\circ} \mathrm{C}$.

\section{Extraction of $S$-adenosyl-L-methionine: uroporphyrinogen III} methyltransferase (SUMT)

E. coli MC1060/pXL1283 was grown at $37^{\circ} \mathrm{C}$ in M9 medium (120 ml) supplemented with ampicillin $\left(100 \mu \mathrm{g} \cdot \mathrm{ml}^{-1}\right)$, casamino acids $(4 \%, \mathrm{w} / \mathrm{v}$, final $)$ and tryptophan $\left(100 \mu \mathrm{g} \cdot \mathrm{ml}^{-1}\right)$ in a baffled shaker flask for $16 \mathrm{~h}$. This culture was then used to inoculate 121 of the same medium but without tryptophan supplement. Growth was continued at $37^{\circ} \mathrm{C}$ to $D_{595} \sim 2$. The culture was chilled, and cells were harvested and lysed as described. To the cell-free extract obtained after centrifugation, pre-swollen DEAE-cellulose $(0.25$ vol. $)$ was added; the mixture was swirled for 5 min and filtered on a water pump. This treatment was repeated with fresh DEAE-cellulose until the filtrate was pale yellow, then solid ammonium sulphate $\left(0.25 \mathrm{~g} \cdot \mathrm{ml}^{-1}\right)$ was added. After being stirred for $1 \mathrm{~h}$, the suspension was centrifuged $(40000 \mathrm{~g}, 45 \mathrm{~min})$, and the pellet obtained could be resuspended for use in enzymic incubations or was frozen in liquid $\mathrm{N}_{2}$ and stored at $-70{ }^{\circ} \mathrm{C}$.

\section{Extraction of $S$-adenosyl-L-methionine: precorrin-2 methyltransferase $\left(\mathrm{SP}_{2} \mathrm{MT}\right)$}

E. coli BL21(DE3)/pLysS/pXL1492 was grown at $37{ }^{\circ} \mathrm{C}$ in LB broth (12 1) supplemented with ampicillin $\left(50 \mu \mathrm{g} \cdot \mathrm{ml}^{-1}\right)$ and chloramphenicol $\left(20 \mu \mathrm{g} \cdot \mathrm{ml}^{-1}\right)$ to $D_{595}=0.65$. After the addition of isopropyl $\beta$-D-thiogalactopyranoside $(0.4 \mathrm{mM}$ final concentration), growth was continued for $2 \mathrm{~h}$. The culture was chilled and cells were harvested and lysed as described. The rest of the enzyme preparation was exactly as for SUMT.

\section{Coupled-enzyme incubations}

Buffers for the incubations were $150 \mathrm{mM} \mathrm{Na}{ }_{2} \mathrm{HPO}_{4} / \mathrm{NaH}_{2} \mathrm{PO}_{4}$ (pH 8.2)/100 mM NaCl (buffer A) and $200 \mathrm{mM}$ $\mathrm{Na}_{2} \mathrm{HPO}_{4} / \mathrm{NaH}_{2} \mathrm{PO}_{4}(\mathrm{pH} \mathrm{8.2)} / 10 \mathrm{mM} \mathrm{NaCl}$ (buffer B); both buffers contained $4 \mathrm{mM}$ dithiothreitol. The buffers for extraction of isobacteriochlorins from the enzyme incubations were $27 \mathrm{mM}$ pyridine adjusted to $\mathrm{pH} 4.1$ with acetic acid (buffer $\mathrm{C}$ ) and $200 \mathrm{mM} \mathrm{Na}{ }_{2} \mathrm{HPO}_{4} / \mathrm{NaH}_{2} \mathrm{PO}_{4}(\mathrm{pH}$ 8.0) (buffer D). Buffers for enzymic incubations, pigment extraction and ester hydrolysis with aqueous piperidine were thoroughly deoxygenated under argon prior to use, and all the steps for preparation of incubation mixtures containing the enzymes were at $0-5^{\circ} \mathrm{C}$.

The volumes of solution used for the directions which follow are related back to the volume of enzyme solution produced from a known concentration of suspended cells (see Lysis of cells section above). In this way, the directions are accurate for any amount of cells used at the outset.

\section{Preparation of uroporphyrin III (9a) and uroporphyrinogen III (4)}

The ammonium sulphate pellet from E. coli AN1459/pPS16 was thawed and resuspended in buffer A containing $10 \mathrm{mM}$ ALA to the volume of the protein solution from the original lysed cells from which the ammonium sulphate pellet was prepared. This mixture was then flushed with argon and incubated at $35^{\circ} \mathrm{C}$ in a constant-temperature environmental shaker in the dark for $6 \mathrm{~h}$ under a slow argon stream. Buffer C (2 vol.) was added and the $\mathrm{pH}$ was adjusted to 4.0 with argon-deoxygenated $2 \mathrm{M} \mathrm{HCl}$. The solution was flushed with argon and precipitated protein was 
removed by centrifugation $\left(40000 \mathrm{~g}, 15 \mathrm{~min}, 4^{\circ} \mathrm{C}\right)$. The supernatant was passed through a reverse-phase C-18 Sep-Pak cartridge [pretreated with $1 \%(\mathrm{v} / \mathrm{v})$ trifluoroacetic acid in ethanol followed by $2 \mathrm{mM}$ aq. $\mathrm{HCl}$ ] which was washed with $5 \%(\mathrm{v} / \mathrm{v})$ acetonitrile in buffer $\mathrm{C}$, and then the adsorbed uroporphyrin III was eluted with $20 \%(\mathrm{v} / \mathrm{v})$ acetonitrile in buffer C. Analysis of the proportions of uroporphyrins I and III was by HPLC as described [32], and uroporphyrin III was estimated by the absorption of its dication in acidic solution at $406 \mathrm{~nm}$.

Alternatively, uroporphyrin III could be isolated as its octamethyl ester. Enough DEAE-cellulose (as a slurry in buffer D) was added to remove the pigments from the incubation mixture and the collected DEAE-cellulose was washed successively with buffer $\mathrm{D}$, water and dry methanol, all being deoxygenated. The cellulose was then washed with deoxygenated $\mathrm{H}_{2} \mathrm{SO}_{4} /$ methanol $(0.025: 1, \mathrm{v} / \mathrm{v})$ to remove all pigments. A volume of trimethyl orthoformate $(99.8 \%)$ was added to the methanolic solution corresponding to $5 \%$ of its volume and the mixture was kept at $18^{\circ} \mathrm{C}$ for $16 \mathrm{~h}$ under argon in the dark. It was then partitioned between water ( 1 vol.) and dichloromethane $(0.25 \mathrm{vol}$.) and the organic solution was washed successively with aq. sodium hydrogen carbonate, water and saturated aq. sodium chloride, then dried $\left(\mathrm{Na}_{2} \mathrm{SO}_{4}\right)$ and evaporated. Purification of the residue by preparative TLC under argon using chloroform/ether $(1: 1$, $\mathrm{v} / \mathrm{v}$, prefiltered through basic alumina) gave uroporphyrin III octamethyl ester. Its identity was confirmed by direct comparison with authentic material using chromatography (TLC) and spectroscopy (UV-visible absorption, ${ }^{1} \mathrm{H}-\mathrm{NMR}$ and mass spectroscopy). This product was hydrolysed by stirring it for $16 \mathrm{~h}$ in a mixture of $2 \mathrm{M} \mathrm{KOH} /$ tetrahydrofuran (THF) $(1: 1, \mathrm{v} / \mathrm{v})$ in the dark under argon. The organic layer was separated and the aqueous phase was freed of THF by partial evaporation. Uroporphyrin III was then reduced to uroporphyrinogen III by adding sufficient freshly prepared $3 \% \mathrm{Na} / \mathrm{Hg}$ under argon to render the solution colourless [33].

\section{Preparation of sirohydrochlorin octamethyl ester (10b)}

Ammonium sulphate pellets of AN1459/pPS16 (2 parts) and MC1060/pXL1283 (5 parts) were thawed and resuspended in a volume of buffer A (containing $10 \mathrm{mM}$ ALA) equal to 5 times the volume of the protein solution from the lysed cells of AN1459/ pPS16 from which the ammonium sulphate pellet was prepared. Solid AdoMet (4 mM final concentration) was added, and the mixture was sealed under argon and then incubated at $35^{\circ} \mathrm{C}$ in a constant-temperature environmental shaker in the dark and under a slow argon stream for $6 \mathrm{~h}$. The product precorrin-2 (5) [34] underwent aerial oxidation during the subsequent handling steps and was isolated as sirohydrochlorin octamethyl ester by the procedure described for uroporphyrin III octamethyl ester; the quantity was determined by its absorption at $588 \mathrm{~nm}$ in dichloromethane $\left[\epsilon=1.75 \times 10^{4} \mathrm{M}^{-1} \cdot \mathrm{cm}^{-1}\right.$ (F. Blanche, personal communication)]. This product was further purified by preparative TLC using dichloromethane/methyl acetate/acetic acid $(20: 5: 1$, by vol.) as solvent to remove small amounts of stereoisomers which are always formed (see the Results and discussion section). The pure natural isomer $\mathbf{1 0 b}$ was used for spectroscopic identification. $\delta_{\mathrm{H}}\left(\mathrm{C}^{2} \mathrm{H}_{2} \mathrm{Cl}_{2}, 400 \mathrm{MHz}\right) 1.78(\mathrm{~s}, 7-\mathrm{Me}), 1.83$ (s, 2$\mathrm{Me}$ ), 1.95-3.0 (multiplets, propionates and acetates), 3.55, 3.57, $3.63(\times 2), 3.62(\times 2), 3.73,3.74(\mathrm{~s}, 8 \times \mathrm{OMe}), 4.05,4.09$ (overlapping dd, $\mathrm{H}-3$ and $\mathrm{H}-8), 4.29\left(\mathrm{~s}, 12-\mathrm{CH}_{2}\right.$ and $18-\mathrm{CH}_{2}$ ), 6.78 (s, H-5), 7.31 (s, H-20), 7.43 (s, H-10), 8.50 (s, H-15).

Sirohydrochlorin octamethyl ester prepared as above from [1$\left.{ }^{13} \mathrm{C}\right]$ ALA showed $\delta_{\mathrm{C}}\left(100.6 \mathrm{MHz}, \mathrm{C}_{6}{ }^{2} \mathrm{H}_{6}\right.$; reference, centre of benzene triplet at 128.00 p.p.m.) $170.00,171.31,171.72,171.75$
$(4 \times$ acetate carbonyl), 173.08, 173.16, 173.24 and $173.25(4 \times$ propionate carbonyl). Found for unlabelled material by electrospray mass spectroscopy: $M H^{+} 975 ; \mathrm{C}_{50} \mathrm{H}_{56} \mathrm{~N}_{4} \mathrm{O}_{16}$ requires $M+\mathrm{H}$ 975.

Sirohydrochlorin octamethyl ester could be safely stored for long periods under argon in the dark at $-70{ }^{\circ} \mathrm{C}$. When needed for enzymic experiments, it was hydrolysed by stirring with $2 \mathrm{M}$ aqueous piperidine in the dark under argon for $48 \mathrm{~h}$.

\section{Preparation of TMIBC octamethyl ester (11b)}

Ammonium sulphate pellets of AN1459/pPS16 (1 part), MC1060/pXL1283 (2 parts) and BL21(DE3)/pLysS/pLX1492 ( 2 parts) were thawed and resuspended in a volume of buffer $B$ (containing $0.65 \mathrm{mM}$ ALA) equal to 50 times the volume of the lysed cells of AN1459/pPS16 from which the ammonium sulphate pellet was prepared. When uroporphyrinogen III was used as substrate, only the ammonium sulphate pellets of MC1060/ pXL1283 (1 part) and BL21(DE3)/pLysS/pLX1492 (1 part) were needed. They were resuspended in a volume of buffer B equal to 5 times the volume of the lysed cells of MC1060/pXL1283, and uroporphyrinogen III was added to a final concentration of $0.03 \mathrm{mM}$. In each case solid AdoMet $(0.33 \mathrm{mM}$ final concentration) was added, the mixtures were sealed under argon and incubated at $35^{\circ} \mathrm{C}$ in a constant-temperature environmental shaker in the dark and under a slow argon stream for $48 \mathrm{~h}$. The product was isolated as TMIBC octamethyl ester by the procedure described for uroporphyrin III octamethyl ester, except that purification by preparative TLC was carried out using dichloromethane/methyl acetate/acetic acid (20:5:1, by vol.). TMIBC octamethyl ester was estimated by its absorption at $588 \mathrm{~nm}$ in dichloromethane $\left[\epsilon=1.92 \times 10^{4} \mathrm{M}^{-1} \cdot \mathrm{cm}^{-1} \quad(\mathrm{~F}\right.$. Blanche, personal communication)] after complete removal of residual acetic acid by purging with a stream of argon. These conditions routinely afforded $15-20 \mathrm{mg}$ of this product from a single $500 \mathrm{ml}$ reaction vessel.

It is possible, using the foregoing TLC system, to separate the pure natural isomer $\mathbf{1 1 b}$ from small amounts of its stereoisomers, and this material was used for spectroscopic identification. $\delta_{\mathrm{H}}$ $\left(\mathrm{C}^{2} \mathrm{H}_{2} \mathrm{Cl}_{2}, 400 \mathrm{MHz}\right) 1.58$ (s, 7-Me), 1.83 (s, 2-Me), 1.9-2.95 (multiplets, propionates and acetates), 2.82 (s, 20-Me), 3.57, 3.58, 3.62, 3.635, 3.645, 3.66, 3.73, 3.75 (all s, $8 \times$ OMe), 3.95 (two overlapping dd, $\mathrm{H}-3$ and $\mathrm{H}-8), 4.22$ (s, 12- $\left.\mathrm{CH}_{2}\right), 4.25$ (AB quartet, $J 18 \mathrm{~Hz}, 18-\mathrm{CH}_{2}$ ), 6.45 (s, H-5), 7.23 (s, H-10), 8.37 (s, H-15).

A sample of the trimethylisobacteriochlorin octamethyl ester prepared as above from $\left[1-{ }^{13} \mathrm{C}\right] \mathrm{ALA}$ showed $\delta_{\mathrm{C}}(100.6 \mathrm{MHz}$, $\mathrm{C}_{6}{ }^{2} \mathrm{H}_{6}$; reference, centre of benzene triplet at 128.00 p.p.m.) $171.17,171.46,171.58,172.19$ (4 $\times$ acetate carbonyl), 172.95, 173.17, 173.22 and $173.24(4 \times$ propionate carbonyl). Found for unlabelled material by electrospray mass spectroscopy: $\mathrm{MH}^{+}$ 989; $\mathrm{C}_{51} \mathrm{H}_{58} \mathrm{~N}_{4} \mathrm{O}_{16}$ requires $M+\mathrm{H} 989$.

The stability of trimethylisobacteriochlorin octamethyl ester in storage and the method for its hydrolysis were as described for sirohydrochlorin octamethyl ester.

\section{Preparation of ${ }^{14} \mathrm{C}$-labelled precorrin-2 (as $\mathbf{5}$ ) and sirohydrochlorin} octamethyl ester (as 10b)

[2,7-methyl $\left.-{ }^{14} \mathrm{C}\right]$ Precorrin-2 was prepared from ALA by the method used for sirohydrochlorin octamethyl ester but now using $\left[\right.$ methyl $\left.-{ }^{14} \mathrm{C}\right]$ AdoMet. This product in a known portion of the incubation mixture was freed from unused [methyl${ }^{14} \mathrm{C}$ ]AdoMet by means of a reverse-phase $\mathrm{C}-18$ cartridge as described for the isolation of uroporphyrin III, and the total ${ }^{14} \mathrm{C}$ activity it contained was determined. The product in the re- 
maining part of the incubation mixture was allowed to undergo aerial oxidation; the resultant sirohydrochlorin was isolated and purified as its pure octamethyl ester and assayed for ${ }^{14} \mathrm{C}$ activity. From the specific activity of the pure sirohydrochlorin and the total activity present in the precorrin-2, the amount of the latter product present at the end of the incubation could be calculated.

\section{RESULTS AND DISCUSSION}

\section{Preparation of uroporphyrinogen III (4)}

The hemB, hemC and hemD genes of B. subtilis were expressed in $E$. coli by cloning the appropriate $B$. subtilis chromosomal fragment from pLUX3201 downstream of the thermoinducible bacteriophage $\lambda P_{\mathrm{R}}$ promoter in the pCE30-derived vector pPS436 to give pPS16. Thermal induction of this heterologous system resulted in the progressive accumulation of several proteins as visualized by SDS/PAGE, and analysis of cell-free extracts prepared from these cultures revealed heightened levels of PBG synthase, HMB synthase and uroporphyrinogen III synthase activities over levels in wild-type $E$. coli. Lysis in the presence of Triton $\mathrm{X}-100$, lysozyme and Tris/HCl buffer provided the optimum conditions for isolation of all three soluble proteins. Precipitation of protein from this cell-free extract using ammonium sulphate then gave a pellet that was ready for resuspension, restoring full enzymic activity for use in enzyme incubations, or for indefinite storage at $-70{ }^{\circ} \mathrm{C}$. The uroporphyrinogen III synthase protein in this preparation has been found to be substantially more thermostable than the corresponding enzymes isolated so far from other sources, all of which are rather labile. It retains $100 \%$ and $90 \%$ activity after $24 \mathrm{~h}$ at $30^{\circ} \mathrm{C}$ and $45^{\circ} \mathrm{C}$ respectively [35]. Thus this enzyme preparation can be used successfully for incubations over long periods.

Incubation of isolated enzyme from AN1459/pPS16 with ALA (1) at $37{ }^{\circ} \mathrm{C}$ led to the rapid accumulation of uroporphyrinogen. However, this was rapidly oxidized to uroporphyrin by air, resulting in the formation of micro-crystals which made quantitative isolation of product difficult. All further incubations were therefore carried out at $\mathrm{pH} 8.0$ in argondegassed buffers, under an argon stream and in the dark, and under these conditions ALA was quantitatively converted into uroporphyrinogen (assayed as porphyrin or porphyrin ester) at a rate of formation of product of $100 \mu \mathrm{g} \cdot \mathrm{h}^{-1} \cdot \mathrm{ml}^{-1}$.

HMB (3) rapidly cyclizes non-enzymically to uroporphyrinogen $\mathrm{I}$ (8) [36], which is not a biosynthetic precursor of the vitamin $B_{12}$. It was therefore necessary to determine the activities of both HMB synthase and uroporphyrinogen III synthase in the prepared cell-free extract; the relative activities found at $\mathrm{pH} 8.0$ were, respectively, 1 and $86 \mu \mathrm{mol}$ of product $\cdot \mathrm{h}^{-1} \cdot \mathrm{ml}^{-1}$. This large excess of uroporphyrinogen III synthase ensures complete conversion of HMB to uroporphyrinogen III (4) and accounts for the observation that only a trace of uroporphyrinogen I could be detected following isolation of pigments and analysis by HPLC.

Although it was possible to measure HMB synthase and uroporphyrinogen III synthase activities directly, the same was not possible for PBG synthase due to the presence of HMB synthase in the extract. Instead, the total PBG synthase activity was estimated by determining the total PBG (2) formed in the standard PBG synthase assay, then the amount of porphyrin that this corresponds to was added to the amount of porphyrin produced in an assay for HMB synthase using ALA as substrate. The activity of PBG synthase at $\mathrm{pH} 8.0$ determined in this way was $40 \mu \mathrm{mol}$ of porphyrin equivalents produced $\cdot \mathrm{h}^{-1} \cdot \mathrm{ml}^{-1}$.

\section{Preparation of SUMT and $\mathrm{SP}_{2} \mathrm{MT}$}

The strategy employed for expression of the $\operatorname{cob} A$ and $\operatorname{cobI}$ genes from $P$ s. denitrificans in E. coli used site-directed mutagenesis to engineer $N d e$ I restriction endonuclease sites over the ATG start codon of each gene. Using these newly constructed $\mathrm{NdeI}$ restriction sites, varying cloning strategies were used to place the $\operatorname{cob} A$ and $\operatorname{cobI}$ genes downstream of the trp and $\mathrm{T} 7$ promoter systems respectively. Expression of the cobA and cobI genes in these heterologous systems led to the accumulation of proteins of $M_{\mathrm{r}} 30000$ and $M_{\mathrm{r}} 26000$ respectively, as visualized by SDS/ PAGE analysis of cell-free extracts (for related work see [11]). The $M_{\mathrm{r}} \mathrm{s}$ of these accumulated proteins agree with the reported $M_{\mathrm{r}}$ for the proteins purified from Ps. denitrificans [12,37] and with the predicted subunit $M_{\mathrm{r}}$ calculated from the amino acid sequence derived from the DNA sequence of the cobA and cobI genes [38,39].

The expression of the Ps. denitrificans cobA gene in E. coli led not only to accumulation of the $\operatorname{cob} A$ gene product, SUMT, but also to the production of substantial amounts of precorrin-2 (5), which underwent oxidation to sirohydrochlorin (10a), as evidenced by the post-induction development of a deep pink pigmentation. In contrast, the expression of the $B$. subtilis enzymes PBG synthase, HMB synthase and uroporphyrinogen III synthase and the Ps. denitrificans cobI gene product in E. coli did not lead to a visible accumulation of pigments in these cultures. The presence of endogenous pigments in enzyme preparations to be used for the biosynthetic assembly of specifically labelled $\mathrm{B}_{12}$ intermediates is undesirable, so endogenous pigments were removed from preparations of SUMT by treating the enzyme preparation with DEAE-cellulose anion-exchange resin.

\section{Preparation of sirohydrochlorin octamethyl ester (10b)}

Precorrin-2 (5) was most successfully prepared by the addition of SUMT directly to a mixture of all the enzymes necessary for uroporphyrinogen III biosynthesis, with AdoMet and ALA as substrates. It was isolated by ion exchange, converted by air oxidation into its didehydro derivative $\mathbf{1 0 a}$ and esterified to give sirohydrochlorin octamethyl ester (10b), which was purified chromatographically. Trial runs established the quantity of SUMT required to use all the uroporphyrinogen III produced under these conditions. By using partially purified SUMT in slight excess in the dark under argon, precorrin-2 (isolated as above) was produced on a preparative scale in $45-50 \%$ overall yield from ALA.

It is interesting that the yield of sirohydrochlorin octamethyl ester (10b), after aerial dehydrogenation of the initial product precorrin-2 then esterification, is substantially lower than the high yield of uroporphyrin III octamethyl ester when both preparations started from ALA. Earlier studies (K. Frobel, unpublished work) had shown that the oxidative conversion of precorrin-2 (5) and precorrin-3A (6) into the corresponding aromatic systems 10a and 11a is very dependent on the conditions used and that lactones can be formed as substantial by-products. Though these by-products were not fully studied in the present work, the foregoing experience suggests that a probable loss of some product by lactonization did occur.

A measure of the true yield in the steps catalysed by SUMT was gained by repeating the foregoing preparation several times using [methyl $\left.-{ }^{14} \mathrm{C}\right]$ AdoMet. By comparing the ${ }^{14} \mathrm{C}$ incorporation at the end of the incubation with the value in the purified octamethyl ester 10b, it was found that SUMT achieves approx. $70 \%$ conversion of the available substrate under the best conditions. 
AdoMet-dependent transmethylation reactions are strongly inhibited by low concentrations of the product, $S$-adenosylhomocysteine (AdoHcy) [40]. SUMT is very sensitive to AdoHcy inhibition [37], with a $K_{\mathrm{i}}(0.32 \mu \mathrm{M})$ which is 20 times less than the $K_{\mathrm{m}}(6.3 \mu \mathrm{M})$ for AdoMet. Under the conditions used for the preparation of precorrin-2, $100 \%$ conversion of substrate into products would yield $>2 \mathrm{mM}$ AdoHcy, which must cause considerable inhibition of SUMT and may account in part for the observed yields of precorrin-2. Dilution and changes to the length of incubation, however, had little or no effect on these yields.

\section{Preparation of TMIBC octamethyl ester (11b)}

Incubation of $\mathrm{SP}_{2} \mathrm{MT}$, the product of cobI gene, together with the enzyme mixture above capable of manufacturing precorrin2 (5) initially led to the production of only trace amounts of precorrin-3A (6) (isolated as TMIBC octamethyl ester, 11b). Successful conversion of precorrin-2 into precorrin-3A was ultimately achieved by diluting the enzymic mixture and extending incubation times. Under these conditions, TMIBC octamethyl ester was prepared in $40-45 \%$ overall yield from ALA. Assuming that the losses during air oxidation, esterification and isolation in this case are similar to those for precorrin-2, the overall conversion of precorrin-2 to precorrin-3A must be approx. $90 \%$.

The octa-ester derivatives of both sirohydrochlorin and TMIBC isolated by a single preparative TLC run were in admixture with the C-3 and C-8 epimers which have constantly been observed with samples from both natural and synthetic sources $[8,9,41]$. These epimers comprised $\sim 30 \%$ of total material recovered and only the major epimer was isolated for spectroscopic characterization. However, both sirohydrochlorin (10a) and TMIBC (11a) were routinely used in admixture with their epimers for enzymic experiments since they are known to equilibrate with the major isomer ([41], F. Blanche, personal communication) and so represent valuable material. The aromatized systems 10a and 11a are reduced enzymically [3] in the incubation mixture used for biosynthetic experiments on vitamin $\mathrm{B}_{12}$ to afford, respectively, precorrin-2 (5) and precorrin-3A (6).

The pure esters of sirohydrochlorin and TMIBC were shown by TLC, HPLC, ${ }^{1} \mathrm{H}-\mathrm{NMR}$, UV-visible and electrospray mass spectrometry to be identical with the esters of natural material $[42,43]$ and those prepared synthetically [8-10].

\section{Preparation of TMIBC octamethyl ester (11b) from uroporphyrinogen III (4)}

When ALA or PBG are used as substrates for the coupledenzyme synthesis described in this paper, sets of at least eight or four labels respectively are introduced into the products. However, some experiments on $\mathrm{B}_{12}$ biosynthesis have required a single label or two labels at specific sites [44,45]. These were prepared from uroporphyrinogen III synthesized non-enzymically by routes tailored to the requirement for specific labelling. This involves the synthesis first of labelled uroporphyrin III octamethyl ester (9b), which is hydrolysed and reduced with sodium amalgam [33] to yield the required uroporphyrinogen III. Incubation of this product with SUMT, $\mathrm{SP}_{2} \mathrm{MT}$ and AdoMet under conditions similar to those used when ALA was the starting material then yielded precorrin-3A (6), which was converted into TMIBC octamethyl ester for isolation as previously. The yield was typically $45-50 \%$ overall from uroporphyrinogen III.

\section{Conclusion}

Five recombinant enzymes have been produced by expression of the corresponding genes in an E. coli host. These have been used as reconstituted multi-enzyme systems which are reasonably stable to biosynthesize, on what for this area is a large scale, complex intermediates involved in the biosynthesis of vitamin $\mathrm{B}_{12}$. The methods described have proved invaluable for the preparation of non-labelled [46,47] and specifically labelled $[44,45,48-50]$ substrates for experiments that have led to important discoveries about the way the essential vitamin $B_{12}$ is synthesized in living organisms [1,2].

Grateful acknowledgement is made to Dr. N. E. Dixon (Australian National University, Canberra, Australia) and Dr. L. Hederstedt (University of Lund, Austria) for valuable gifts of plasmid DNA, the Royal Society for a grant for scientific exchanges (to A.A.Y.), and Schering A.G. (Berlin, Germany) for the Schering Postdoctoral Fellowship (held by A.R.P.). Grateful acknowledgement is made to Zeneca, Roche Products, F. Hoffmann-La Roche, Rhône-Poulenc-Rorer and EPSRC for financial support. We also thank Drs. F. J. Leeper, C. Abell, F. Blanche, D. Thibaut and L. Debussche for helpful discussions, L. Cauchois for excellent technical assistance, T. Ciora for oligonucleotide synthesis, and J. Lunel and J.-C. Brunie for their support.

\section{REFERENCES}

1 Blanche, F., Cameron, B., Crouzet, J., Debussche, L., Thibaut, D., Vuilhorgne, M., Leeper, F. J. and Battersby, A. R. (1995) Angew. Chem. Int. Ed. Engl. 34, 383-411

2 Battersby, A. R. (1994) Science 264, 1551-1557

3 Thibaut, D., Debussche, L. and Blanche, F. (1990) Proc. Natl. Acad. Sci. U.S.A. 87, 8795-8799

4 Thibaut, D., Blanche, F., Debussche, L., Leeper, F. J. and Battersby, A. R. (1990) Proc. Natl. Acad. Sci. U.S.A. 87, 8800-8804

5 Battersby, A. R. (1993) Acc. Chem. Res. 26, 15-21

6 Scott, A. I. (1990) Acc. Chem. Res. 23, 308-317

7 Stamford, N. P. J. (1994) Ciba Found. Symp. 180, 247-262

8 Block, M. H., Zimmerman, S. C., Henderson, G. B., Turner, S. P. D., Westwood, S. W., Leeper, F. J. and Battersby, A. R. (1985) J. Chem. Soc. Chem. Commun. 1061-1063

9 Whittingham, W. G., Ellis, M. K., Guerry, P., Henderson, G. B., Müller, B., Taylor, D. A., Leeper, F. J. and Battersby, A. R. (1989) J. Chem. Soc. Chem. Commun. 1116-1119

10 Müller, B., Collins, A. N., Ellis, M. K., Whittingham, W. G., Leeper, F. J. and Battersby, A. R. (1989) J. Chem. Soc. Chem. Commun. 1119-1122

11 Warren, M. J., Roessner, C. A., Ozaki, S. I., Stolowich, N. J., Santander, J. and Scott, A. I. (1992) Biochemistry 31, 603-609

12 Thibaut, D., Couder, M., Crouzet, J., Debussche, L., Cameron, B. and Blanche, F. (1990) J. Bacteriol. 172, 6245-6251

13 Vasudevan, S. G., Armarego, W. L. F., Shaw, D. C., Lilley, P. E., Dixon, N. E. and Poole, R. K. (1991) Mol. Gen. Genet. 226, 49-58

14 Casadaban, M. J., Martinez-Arias, A., Shapira, S. T. and Chou, J. (1983) Methods Enzymol. 100, 293-308

15 Studier, F. and Moffatt, B. (1986) J. Mol. Biol. 189, 113-130

$15 a$ Gibson, T. J. (1984) Ph.D. Thesis, University of Cambridge

15b Stamford, N. P. J. (1991) Ph.D. Thesis, Australian National University

16 Denèfle, P., Kovarik, S., Guiton, J.-D., Cartwright, T. and Mayaux, J.-F. (1987) Gene 56, 61-70

17 Chang, A. C. and Cohen, S. N. (1978) J. Bacteriol. 134, 1141-1156

18 Rosenberg, A. H., Lade, B. N., Chui, D.-S., Lin, S.-W., Dunn, J. J. and Studier, F. W. (1987) Gene 56, 125-135

19 Cameron, B., Briggs, K., Pridmore, S., Brefort, G. and Crouzet, J. (1989) J. Bacteriol. 171, 547-557

20 Hansson, M., Rutberg, L., Schröder, I. and Hederstedt, L. (1991) J. Bacteriol. 173, 2590-2599

21 Messing, J. and Vieira, J. (1982) Gene 19, 269-276

22 Kieny, M. P., Lathe, R. and Lecocq, J. P. (1983) Gene 26, 91-99

23 Sambrook, J., Fritsch, E. F. and Maniatis, T. (1989) Molecular Cloning: A Laboratory Manual, 2nd edn., Cold Spring Harbor Laboratory, Cold Spring Harbor, NY

24 Hart, G. J., Abell, C. and Battersby, A. R. (1986) Biochem. J. 240, 273-276

25 Zav'yalov, S. I., Aranova, N. I., Makhova, N. N. and Vol'kenshtein, Yu. B. (1973) Izv. Akad. Nauk SSSR Ser. Khim. 3, 657-658

26 Battersby, A. R., McDonald, E., Wurziger, H. K. W. and James, K. J. (1975) J. Chem. Soc. Chem. Commun. 493-494

27 Elvin, C. M., Thompson, P. R., Argall, M. E., Hendry, P., Stamford, N. P. J., Lilley, P. E. and Dixon, N. E. (1990) Gene 87, 123-126

28 Nakamaye, K. and Eckstein, F. (1986) Nucleic Acids Res. 14, 9679-9698 
29 Mitchell, L. W. and Jaffe, E. K. (1993) Arch. Biochem. Biophys. 300, 169-177

30 Hart, G. J., Leeper, F. J. and Battersby, A. R. (1984) Biochem. J. 222, 93-102

31 Hart, G. J. and Battersby, A. R. (1985) Biochem. J. 232, 151-160

32 Rossi, E. and Curnow, D. H. (1986) in HPLC of Small Molecules: A Practical Approach (Lim, C. K., ed.), pp. 261-303, IRL Press, Oxford

33 Battersby, A. R., McDonald, E., Hollenstein, R., Ihara, M., Satoh, F. and Williams, D. C. (1977) J. Chem. Soc. Perkin Trans. 1 166-178

34 Battersby, A. R., Frobel, K., Hammerschmidt, F. and Jones, C. (1982) J. Chem. Soc. Chem. Commun. 455-457

35 Stamford, N. P. J., Capretta, A. and Battersby, A. R. (1995) Eur. J. Biochem. 231 236-241

36 Battersby, A. R., Fookes, C. J. R., Gustafson-Potter, K. E., McDonald, E. and Matcham, G. W. J. (1982) J. Chem. Soc. Perkin Trans. 1 2447-2444

37 Blanche, F., Debussche, L., Thibaut, D., Crouzet, J. and Cameron, B. (1989) J. Bacteriol. 171, 4222-4231

38 Crouzet, J., Cauchois, L., Blanche, F., Debussche, L., Thibaut, D., Rouyez, M.-C., Rigault, S., Mayaux, J.-F. and Cameron, B. (1989) J. Bacteriol. 172, 5968-5979

39 Crouzet, J., Cameron, B., Cauchois, L., Rigault, S., Rouyez, M.-C., Blanche, F. Thibaut, D. and Debussche, L. (1989) J. Bacteriol. 172, 5980-5990

40 Ueland, P. M. (1982) Pharmacol. Rev. 34, 223-253

41 Battersby, A. R., McDonald, E., Neier, R. and Thompson, M. (1979) J. Chem. Soc. Chem. Commun. 960-961
42 Battersby, A. R., McDonald, E., Morris, H. R., Thompson, M., Williams, D. C., Bykhovsky, V. Y., Zaitseva, N. I. and Bukin, V. N. (1977) Tetrahedron Lett. 2217-2220

43 Battersby, A. R., Matcham, G. W. J., McDonald, E., Neier, R., Thompson, M., Woggon, W.-D., Bykhovsky, V. Y. and Morris, H. R. (1979) J. Chem. Soc. Chem. Commun. 185-186

44 Blanche, F., Kodera, M., Couder, M., Leeper, F. J., Thibaut, D. and Battersby, A. R. (1992) J. Chem. Soc. Chem. Commun. 138-139

45 Alanine, A. I. D., Ichinose, K., Thibaut, D., Debussche, L., Stamford, N. P. J., Leeper, F. J., Blanche, F. and Battersby, A. R. (1994) J. Chem. Soc. Chem. Commun. 193-195

46 Balachandran, S., Vishwakarma, R. A., Monaghan, S. M., Prelle, A., Stamford, N. P. J., Leeper, F. J. and Battersby, A. R. (1994) J. Chem. Soc. Perkin Trans. 1 487-491

47 Alanine, A. I. D., Li, Y., Stamford, N. P. J., Leeper, F. J., Blanche, F., Debussche, L. and Battersby, A. R. (1994) J. Chem. Soc. Chem. Commun. 1649-1650

48 Li, Y., Stamford, N. P. J. and Battersby, A. R. (1995) J. Chem. Soc. Perkin Trans. 1 283-284

49 Vishwakarma, R. A., Balachandran, S., Alanine, A. I. D., Stamford, N. P. J., Kiuchi, F., Leeper, F. J. and Battersby, A. R. (1993) J. Chem. Soc. Perkin Trans. 1 2893-2899

50 Li, Y., Alanine, A. I. D., Vishwakarma, R. A., Balachandran, S., Leeper, F. J. and Battersby, A. R. (1994) J. Chem. Soc. Chem. Commun. 2507-2508

Received 24 April 1995/7 August 1995; accepted 25 August 1995 